\title{
Airport Passenger Terminal in Buleleng, Bali Circulation Pattern in The Design Of Airport Passenger Terminals in Buleleng
}

\author{
Danton Suwanda $^{1}$, Widiastuti ${ }^{2}$, I Ketut Mudra ${ }^{3}$ \\ Bachelor Degree of Architecture Study Program \\ Faculty of Engineering-Udayana University \\ Jimbaran \\ danton.suwanda22@gmail.com \\ Architecture Study Program \\ Faculty of Engineering-Udayana University \\ Jimbaran \\ Architecture Study Program \\ Faculty of Engineering-Udayana University \\ Jimbaran
}

\begin{abstract}
The transportation system is experiencing rapid development. One of the transportation systems that has developed qiote rapidly and is in great demand now is the air transportation system. The air transportation system is the main choice because air transportation can save the travel time when the distance is far enough. Development of time and technology, the increasing demand for air transportation has caused a lack of capacity at Bali's airport. It is necessary to design a facility that can provide a place for air accommodation to accommodate the needs of air transportation users. Circulation is one thing that must be considered when designing an airport passenger terminal. Circulation are usually formed from a pattern of spatial structure so the circulation in the building will determine the smooth activity in the build- ing.
\end{abstract}

Index Terms - transportation, circulation, terminal.

\section{INTRODUCTION}

Airport passenger terminals are a major component in the design of an airport. Quoted from LLAJ's 2005 technical guidelines, the passenger terminal is a means of transportation that serves to raise and lower passengers. Airport has the understanding as a land area or water that has a certain limit, is used as an aircraft landing area and also taking off, the ups and downs of passengers, loading and unloading of goods and also the transportation authority (Law No. 1 of 2009 concerning flights). The airport passenger terminal has a function as a container for passengers to carry out activities related to air transport needs such as purchasing tickets, baggage and completing checks.
Tourist interest in tourism destinations in Buleleng Regency can be known from the static data of tourists visiting Buleleng Regency. Statistics show that from 2012 to 2016, tourist visits to the Regency of Buleleng increased by $0.85 \%$ from the initial visit of 580,120 tourists to 282,019 tourists. These statistical data prove that the interest of tourists to visit Buleleng Regency is quite high. The high interest of tourists to

visiting Buleleng certainly needs to be supported by an adequate mode of transportation considering that Buleleng Regency is located in the northern part of Bali Island and requires approximately up to three hours drive from Denpasar City if taken by land transportation. A new airport facility is needed in parts of North Bali that is capable of supporting infrastructure in Buleleng Regency. The airport in Buleleng is an effort to assist the operation of Ngurah Rai International Airport, which has experienced a swelling 
number of tourists each year. Another goal of designing the airport passenger terminal in Buleleng is to provide air transportation mode facilities in the North Bali area, equitable distribution of tourism zones in the Bali area and also increase the development of tourism and the economy of the people around North Bali.

\section{RESUlt AND ANALISYS}

\section{A. Theme of Design}

Appropriate circulation patterns in a building design can help achieve the smoothness of existing activities in the building. Franchis D.K. Ching in his book entitled Architectural theory (19930 states that the pattern of circulation can be said to be a "rope" that binds spaces.

Circulation systems that are generally applied to airport terminals are of two types, namely the circulation pattern of a single-story system or a single system and also a multilevel system. The one-story circulation system is a circulation system in which all activities occur on the same floor as the apron floor. Multilevel floor system is a circulation system in which the separation of the movement of passengers and baggage flows. This separation means that at the airport terminal one-way currents occur and are not mutually interrupted. The circulation pattern of one floor is divided into two types, namely the one floor A system and the one floor B system. The one floor A system is generally applied to airport buildings that tend to have a smaller area, whereas the one floor B system has different functions where passengers do not need go up to the pesron apron. The circulation pattern of one floor can be seen in the following figure 1 .
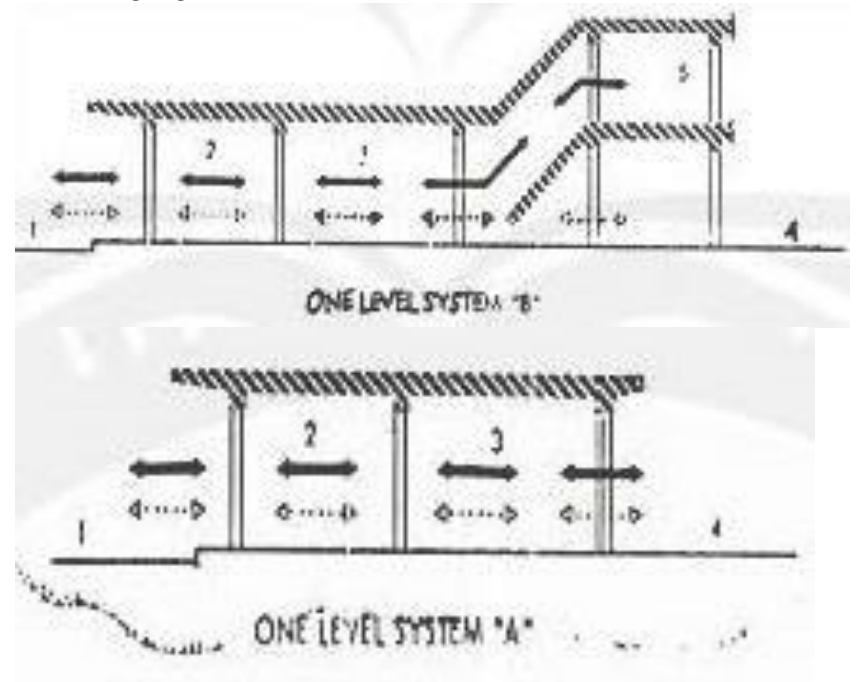

Fig. 1. One-Floor Circulation Pattern (source: Swanda:2017)

In addition to the circulation pattern of one floor, multilevel circulation pattern or multi-level system is also divided into several types, namely multi-level circulation system $\mathrm{C}$ system where the passage of passengers and baggage is centered on the same apron floor as the waiting floor due to the apron being one floor below the room Wait.
The multi-level circulation system of the D system has a arrival and departure civitas circulation not carried out on the same floor. The following is a picture of a multi-level circulation system C and D which can be seen in Figure 2.

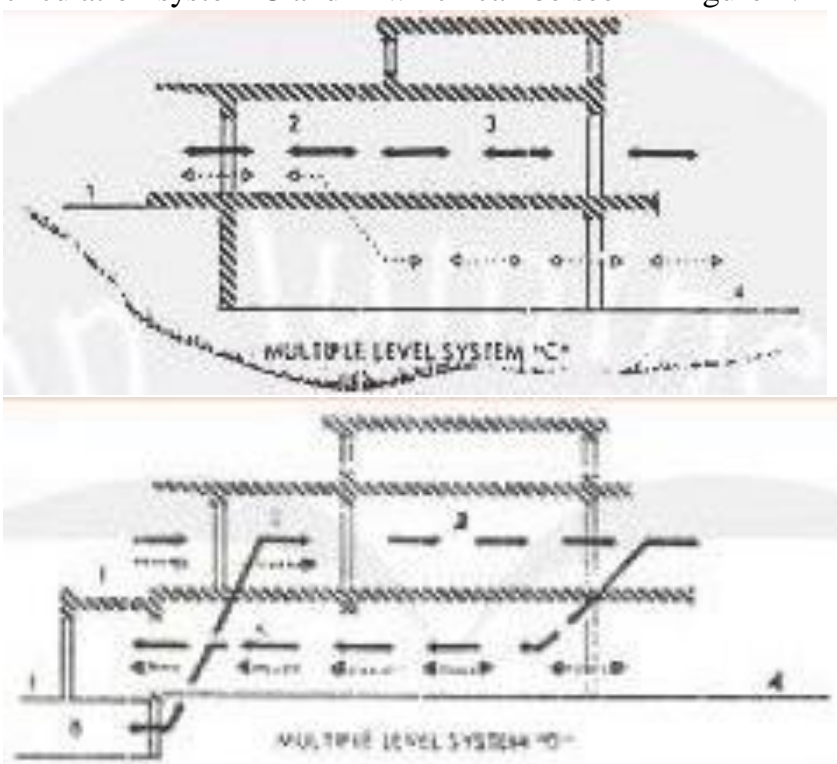

Fig. 2. Multi Level C and D Circulation Pattern (source: Swanda:2017)

In addition to the circulation patterns of the $\mathrm{C}$ and $\mathrm{D}$ systems, the multi-level circulation patterns of the $\mathrm{E}$ system have a civitas circulation system that is designed in the same position at the time of arrival and departure so that the system is appropriate for use in passenger terminals which have relatively dense visitor capacity. The multi-level circulation system $\mathrm{F}$ has a circulation pattern in which passenger and luggage management activities are carried out on the third floor apron so that this circulation system is suitable for use on sites that have steep contours. Beriky is a picture of a multi-level circulation system $\mathrm{E}$ and $\mathrm{F}$ which can be seen in Figure 3.

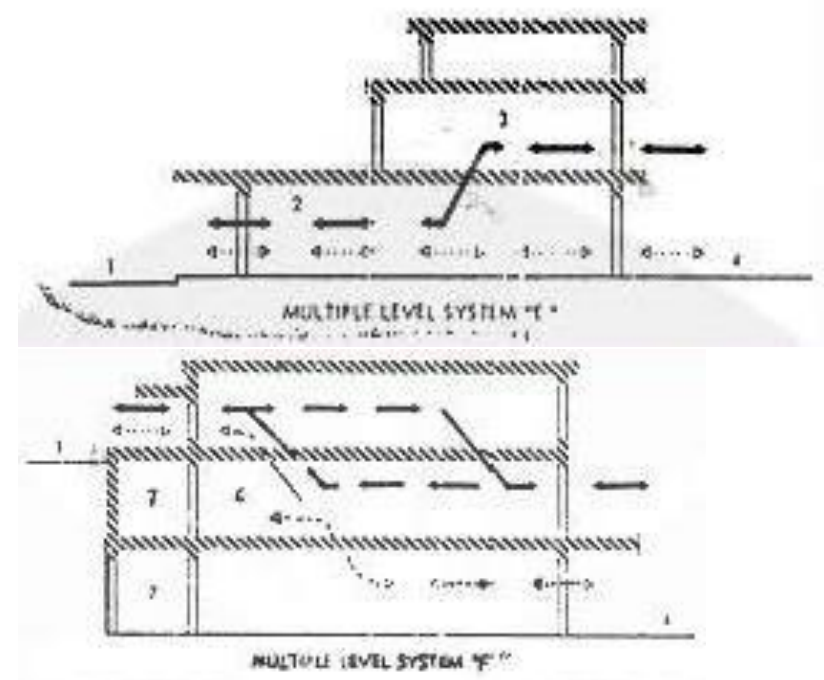

Fig. 3. Multi-level Circulation System E and F (source: Swanda:2017)

Determination of circulation patterns at the Airport Passenger Terminal in Buleleng is done by approaching it through a schematic design. Schematic design of circulation 
patterns in buildings is determined by the flow of the civitas and the goods. The flow of the civitas circulation will form a circulation pattern in the building which then will produce a spatial organization. The following is the flow of the community at the airport passenger terminal which can be seen in Figure 3.

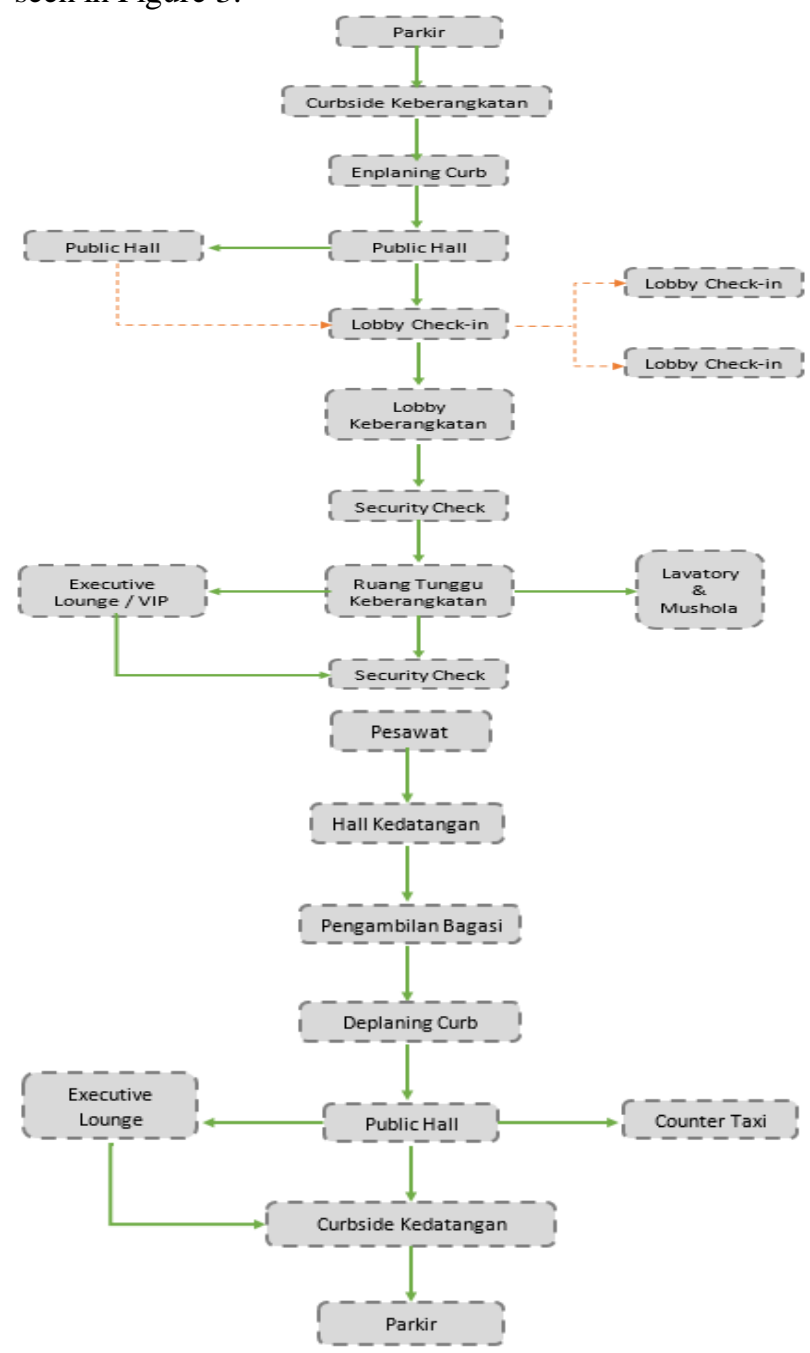

Fig. 4. Flow of Civitas Arrival and Departure (source: Swanda:2017)

\section{B. Circulation Patterns in Air Passenger Terminals in Buleleng}

The application of circulation patterns at the airport passenger terminal in Buleleng refers to the multi-level circulation system of the E system. The concept of multilevel circulation is the concept of vertical circulation at the airport passenger terminal which is most effectively used. In this multi-level system, service activities for both passengers and goods will be differentiated according to their needs. Activity at the airport passenger terminal in Buleleng will be separated according to type vertically. The first floor will be used as the operating area for departure passengers, passenger, luggage and baggage, while the second floor will be used as a concession area and the terminal waiting room. The first floor and the second floor are used respectively operational activities such as management and administrative activities. As stated in the decision of the director general of air transportation regarding the standard design of engineering facilities and airport facilities that the multi-level circulation system E system is a circulation pattern in which the circulation paths of the civitas at the airport terminal are not on the same floor. The horizontal application of the multi-level circulation pattern E system can be seen in Figure 5.

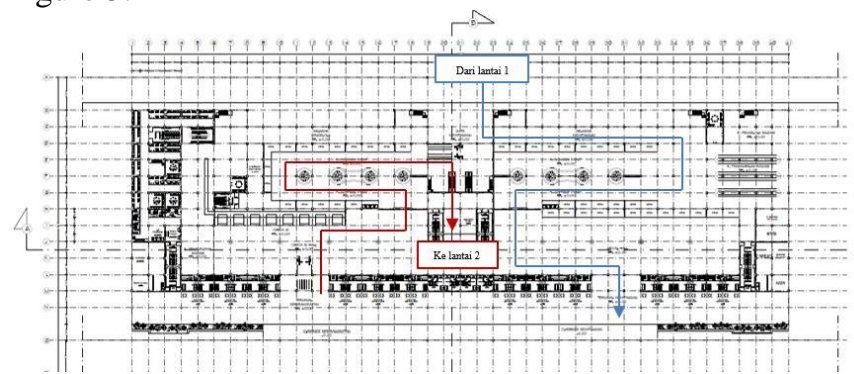

Fig. 5 Circulation Pattern E (source: Swanda:2017)

The circulation patterns of passengers arriving and departing are not on one floor. The departure passenger first checks the ticket and passenger identity and passes the first security check. After conducting a security check, passengers will enter the lobby check in to check in luggage and departures and then passengers will be directed to the land concession room, in the land concession room there are retailers that sell various kinds of goods and souvenirs. The activity is carried out on the first floor, after which passengers can wait for departure in the terminal waiting room which is on the second floor of the passenger terminal. Arrival passengers will enter the arrival gate and will collect baggage at the baggage conveyor. Each arrival and departure terminal has a different concession room, so that after the arrival passenger takes the bar, the arrival passenger will go through the air concession room. In addition to the passenger community, to enter the management civitas terminal building, the security check will first enter to check identity. After going through the security check the manager goes through the check-in hall and will enter the management hall which is on the west side of the terminal building. The vertical circulation pattern of the multi-level passenger terminal $\mathrm{E}$ system can be seen in Figure 6.

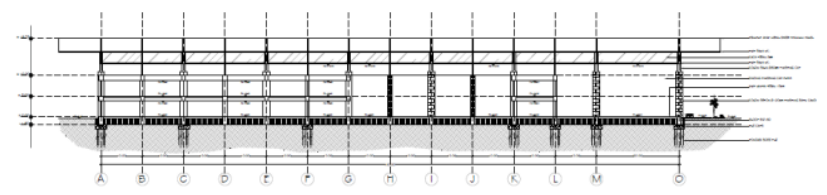

Fig. 6. Multi-Level Passenger Terminal E

Unlike the departure passenger lane, all passenger arrival activities are carried out on the first floor so that there will be no buildup of passenger flow. The advantage of implementing this circulation system is to avoid the accumulation of currents at the arrival and departure terminals because this multi-level circulation pattern is suitable for use in passenger terminals with relatively congested visitors. 
Journal of a Sustainable Global South, p-ISSN: 2579-6062

\section{CONCLUSION}

The airport passenger terminal in Buleleng is a facility designed to support infrastructure in the field of air accommodation in North Bali. The design process, the airport passenger terminal in Buleleng applies a multi-level circulation pattern. The application of multi-level circulation patterns at the airport passenger terminal in Buleleng can be seen from the existence of vertical circulation in buildings where there are two types of circulation carried out on two different floors, namely the defense carried out on the first floor and departures carried out on the second floor. This type of multi-level circulation pattern of $\mathrm{E}$ was chosen because this pattern is suitable for use in passenger terminals which have relatively dense visit rates, thereby reducing the accumulation of circulating currents between passengers arriving and departing. Good circulation in the building is expected to create a smooth activity that occurs in it.

\section{REFERENCES}

[1] . 